\title{
Respon Psikososial dan Strategi Koping Pasien Stroke dalam Konteks Budaya Ambon
}

\author{
Sanci Natalia Loupatty ${ }^{1}$, Yulius Yusak Ranimpi ${ }^{2}$, Rosiana Eva Rayanti ${ }^{3}$ \\ ${ }^{1,3}$ Fakultas Kedokteran dan Ilmu Kesehatan, Universitas Kristen Satya Wacana, Indonesia \\ ${ }^{2}$ Fakultas Teologi, Universitas Kristen Satya Wacana, Indonesia \\ Email: yulius.ranimpi@staff.uksw.edu
}

\begin{abstract}
Psychosocial Response and Strategy Coping of Stroke Patient in Ambon Cultural Context. Stroke is the dissolution of blood flow to the brain, due to the rupture of blood vessels or blockage of blood vessels to the brain. Stroke results in paralysis, sensory disorders, activity disorders, mental changes such as impaired thinking, awareness, concentration, impaired communication, and emotional disturbance. These changes require the ability of individuals to overcome these problems. This ability is known by the term strategy coping. In general, the known strategy of coping is problem-focused coping and emotion-focused coping. As part of the behavior, psychosocial responses and coping strategies influenced by culture. This study aims to describe the psychosocial response and coping strategy of stroke patients in the context of the culture in Ambon. The method in this study is a qualitative phenomenology approach. Data collection techniques used were in-depth interviews. The participants in this study were four people. Result obtained four themes: (1) physical changes, (2) independence in carrying out activities, (3) psychosocial responses, and (4) coping strategies in a cultural context. Physical changes experienced by participants due to stroke give rise to maladaptive and adaptive psychosocial responses. The coping strategies used to overcome the problem are emotional coping and focus coping issues that are influenced by Ambon culture.
\end{abstract}

Keywords: Ambon, Coping strategy, Psychosocial response, Stroke

\begin{abstract}
Abstrak: Respon Psikososial dan Strategi Koping Pasien Stroke dalam Konteks Budaya Ambon. Stroke adalah terputusnya aliran darah ke otak, akibat pecahnya pembuluh darah atau tersumbatnya pembuluh darah ke otak. Stroke mengakibatkan kelumpuhan, gangguan indra rasa, gangguan beraktivitas, perubahan mental seperti gangguan daya pikir, kesadaran, konsentrasi, gangguan dalam berkomunikasi, dan gangguan emosional. Perubahan tersebut membutuhkan kemampuan individu untuk mengatasi persoalan tersebut. Kemampuan tersebut dikenal dengan istilah strategi koping. Secara umum, strategi koping yang dikenal adalah problem focused coping dan emotion focused coping. Sebagai bagian dari perilaku, respon psikososial dan strategi koping dipengaruhi oleh budaya. Penelitian bertujuan mendeskripsikan respon psikososial dan strategi koping pasien stroke dalam konteks budaya di Ambon. Metode dalam penelitian ini adalah kualitatif dengan pendekatan fenomenologi. Teknik pengumpulan data yang digunakan adalah wawancara mendalam. Partisipan dalam penelitian ini berjumlah empat orang. Hasil penelitian mendapatkan empat tema yaitu: (1) perubahan fisik, (2) ketidakmandirian dalam melakukan aktivitas, (3) respon psiko-sosial dan (4) strategi koping dalam konteks budaya. Perubahan fisik yang dialami partisipan akibat stroke menimbulkan respon psikososial berupa maladaptif dan adaptif. Adapun strategi koping yang digunakan untuk mengatasi masalah adalah dengan emotional coping dan problem focus coping yang dipengaruhi oleh budaya Ambon.
\end{abstract}

Kata kunci: Ambon, Strategi koping, Respon psikososial, Stroke

\section{PENDAHULUAN}

Menurut Badan Kesehatan Dunia (World Health Organization, dalam Ghani dkk., 2016), stroke adalah terputusnya aliran darah ke otak, akibat pecahnya pembuluh darah atau tersumbatnya pembuluh darah ke otak sehingga pasokan nutrisi dan oksigen ke otak berkurang. Terjadi peningkatan jumlah pasien stroke di beberapa negara sebesar 1,1 juta pertahun pada tahun 2000 menjadi 1,5 juta pertahun pada tahun 2025 (Ghani dkk., 2016). Menurut laporan Riskesdas pada tahun 2007, pravelensi stroke di Indonesia berdasarkan wawancara sebesar $8,3 \%$ 
dan meningkat menjadi 12,1 pada tahun 2013. Pravelensi stroke pada tahun 2013 di Maluku sebesar $8,7 \%$ (Badan Penelitian dan Pengembangan Kesehatan, 2014). Yayasan Stroke Indonesia melaporkan bahwa Indonesia menduduki urutan pertama di Asia dengan prevalensi stroke mencapai 8,3 dari 1000 populasi (Yastroki, 2012).

Gangguan kesehatan yang dialami seseorang stroke bukan hanya menganggu aspek fisik tetapi psikologis juga yang akan berdampak pada keadaan psikososialnya. Keadaan tersebut mengakibatkan penderita stroke merasa sebagai individu yang tidak berguna dalam melakukan berbagai aktivitas yang berisiko terhadap kualitas hidup, dan dapat menimbulkan tekanan psikologis seperti stres, cemas, hilangnya tujuan hidup, dan gangguan bersosialisasi (Hastuti, 2014). Seseorang yang memiliki masalah psikososial akibat stroke memiliki kecemasan, frustasi yang dapat mengakibatkan depresi, perasaan malu, kecewa, harga diri rendah dan gangguan sosial (Hartanti, 2012; Herawati, 2014). Respon psikososial yang umum dialami penderita yaitu respon maladaptif seperti penolakan terhadap keadaan, ketidakpatuhan, agresif, sensitif emosional, perubahan peran dalam keluarga dan melakukan hal-hal yang dapat mencelakai diri sendiri (Fahrudin \& Wahyuni, 2004).

Penyakit stroke dapat menimbulkan beberapa perubahan fisik dan psikologis. Perubahan fisik yang dialami oleh penderita stroke diantaranya kelumpuhan, gangguan indra rasa, gangguan dalam beraktivitas sedangkan perubahan mental seperti gangguan daya pikir, kesadaran, konsentrasi, gangguan dalam berkomunikasi, dan gangguan emosional berupa marah, sedih dan merasa tidak berdaya (Yuanita, dkk., 2015). Respon psikososial pada penderita stroke akibat perubahan fisik adalah merasa terasing dari orang-orang dan mereka memiliki persepsi bahwa dirinya tidak berguna lagi, karena hidup mereka lebih banyak bergantung pada orang lain (Hasan \& Rufaidah, 2013). Penderita mengalami keterbatasan dalam melakukan kontak sosial, tidak mau bersosialisasi dan perubahan peran di masyarakat. Penderita tidak bisa bersosialisasi dengan orang lain seperti dulu karena merasa malu dengan kondisinya yang tidak mampu melakukan berbagai aktivitas (Herawati, 2014).

Perubahan yang terjadi akibat penyakit yang diderita, penderita perlu mempunyai kemampuan untuk mengatasi dan mengelola masalah yang dialaminya. Kemampuan itu dikenal dengan strategi koping. Strategi koping ialah upaya khusus baik secara perilaku maupun psikologis, yang digunakan oleh setiap individu untuk menguasai, mentoleransi, mengurangi, menangani dampak dari kejadian yang menimbulkan stress (Maulanadari, 2010).

Strategi koping meliputi dua tipe yaitu problem focused coping dan emotion focused coping. Problem focused coping ialah koping yang muncul terfokus pada masalah individu yang akan mengatasi stres dengan mempelajari cara-cara keterampilan yang baru sedangkan emotion focused coping ialah bentuk koping yang diarahkan untuk mengatur respon emosional terhadap situasi yang menekan (Safaria \& Nofrans, 2012). Faktor-faktor yang dapat mempengaruhi strategi koping yaitu strategi koping yaitu strategi koping internal ialah faktor yang berasal dari dalam diri individu, seperti karakteristik sifat kepribadian dan faktor eksternal ialah faktor yang berasal dari luar diri individu, seperti waktu, uang, pendidikan, kualitas hidup, dukungan spiritual, dukungan keluarga dan sosial. Tanpa strategi koping yang efektif maka fungsi afektif, sosial, ekonomi dan perawatan keluarga tidak dapat dicapai secara adekuat (Prawesti, 2013).

Seseorang juga dapat mengatasi stres dan kecemasan dengan menggerakkan sumber koping di lingkungan yang berupa modal ekonomi, kemampuan penyelesaian masalah, dukungan sosial dan keyakinan budaya (Taluta, 2014). Budaya mempengaruhi respon psikososial dan strategi koping seseorang karena nilai-nilai, keyakinan, tradisi, sikap dan prasangka pada individu sudah ada sejak lahir dan berdasarkan pengalaman masa lalu sehingga mempengaruhi interaksi individu dengan orang lain. Budaya merupakan pikiran, akal budi, adat istiadat, agama yang sudah menjadi kebiasaan yang sukar diubah (Amalia, 2010).

Budaya orang Ambon yaitu masyarakat yang memiliki sifat religius magis, sehingga dalam kehidupan kesehariannya selalu mengutamakan keharmoniasan hubungan dengan alam sekitarnya dan terutama Tuhan Pencipta alam semesta serta memiliki rasa kebersamaan yang tinggi (Suantika, 2007). Masyarakat Ambon meyakini bahwa penyakit yang dialami berasal dari kekuatan-kekuatan supernatural seperti roh halus dan adanya pelanggaran aturan adat serta orang yang tidak menepati janji. Pemaknaan ini yang mempengaruhi respon masyarakat terhadap penyakit atau masalah kesehatan yang dialami yaitu dengan menggunakan pendekatan tradisional (Suantika, 2007). Mereka percaya bahwa orang-orang pintar (dukun) dapat menyembuhkan penyakit yang diderita sehingga 
mereka sudah tahu kapan dan di mana harus mencari pengobatan ketika sakit (Gorman \& Sultan, 2008). Berdasarkan permasalahan yang telah diuraikan di atas, maka penelitian bertujuan untuk menganalisa respon psikososial dan strategi koping pasien stroke dalam konteks budaya di Ambon.

\section{METODE}

Penelitian ini menggunakan jenis penelitian kualitatif dengan tipe pendekatan fenomenologi deskriptif. Penelitian ini berlangsung di Ambon pada bulan April-Mei 2018. Partisipan dalam penelitian ini adalah pasien stroke yang berjumlah empat orang yang datanya diambil dari Puskesmas Benteng Ambon. Partisipan ditentukan dengan metode purposive sampling dengan kriteria orang dewasa yang menderita penyakit stroke ringan. Mengumpulkan data dengan cara wawancara semi terstruktur, panduan wawancara berdasarkan indikator dari respon psikososial dan strategi koping. Triangulasi data dalam penelitian ini adalah triangulasi sumber dari keluarga yaitu istri, anak dan cucu partisipan. Teknik analisa data dalam penelitian ini adalah model teori Miles dan Huberman yang memiliki empat yaitu pengumpulan data, reduksi data, penyajian data, dan penarikan kesimpulan (Sugiyono, 2009).

Penelitian ini telah mendapat persetujuan etik (ethical approval) dari Komite Etik Penelitian Kesehatan Fakultas Kedokteran dan Ilmu Kesehatan Universitas Kristen Satya Wacana Nomor: 013/PE/KEPK.UKSW/2018.

\section{HASIL}

\section{Profil Partisipan}

Partisipan dalam penelitian ini adalah pasien post stroke berjumlah empat orang yang menderita lebih dari dua tahun karena sesuai dengan kriteria yang ditentukan. Karakteristik partisipan dapat dilihat pada tabel 1 di bawah ini.

Tabel 1. Karakteristik Partisipan

\begin{tabular}{ccccccl}
\hline Kode & Usia & JK & Pekerjaan & Agama & Lama Menderita Stroke & Kelemahan yang dialami \\
\hline P1 & 50 & P & Wirausaha & Kristen Protestan & 3 tahun & tangan dan kaki kiri \\
P2 & 60 & P & Pensiunan & Kristen Protestan & 2 tahun & tangan dan kaki kiri \\
P3 & 62 & L & Wirausaha & Kristen Protestan & 5 tahun & tangan dan kaki kanan \\
P4 & 67 & P & pensiunan & Kristen Protestan & 3 tahun & tangan dan kaki kanan \\
\hline
\end{tabular}

Berdasarkan hasil wawancara dengan partisipan didapatkan empat tema yaitu perubahan fisik akibat stroke, ketidakmandirian dalam melakukan aktivitas akibat stroke, respon psiko-sosial dan strategi koping dalam konteks budaya.

\section{Perubahan Fisik Akibat Stroke}

Stroke adalah suatu penyakit yang mengakibatkan perubahan fisik. Perubahan fisik akibat stroke adalah suatu keadaan yang dialami partisipan sehingga partisipan tidak dapat melakukan sesuatu dengan mandiri. Perubahan fisik yang dialami seperti tubuh menjadi kaku, artikulasi dalam berbicara kurang jelas, tangan kiri mengecil, dan berjalan tidak sempurna sehingga membutuhkan bantuan orang lain. Hal ini dapat dilihat dari hasil wawancara partisipan:

"Perubahan fisik yang ibu alami berbicara tidak terlalu jelas (lidah pende), tubuh bagian kiri kaku dan tangan kiri mengecil" (P1, 80-90).

"Sekarang yang ibu rasakan lemas, bicara tidak jelas (lidah pende) dan tubuh bagian kiri kaku” (P2, 60-70)
"Bapak punya bagian pinggang sampai di kaki kaku tidak terasa apa-apa kalau cubit juga tidak rasa. Sekarang berjalan sudah sangat susah" (P3, 90-100).

"Mama punya badan kanan kaku, tidak dapat berjalan dengan sendiri dan badan bagian kiri terasa lemas, karena sudah jarang aktivitas" (P4, 100-110).

\section{Ketidakmandirian dalam Melakukan Aktivitas Akibat Stroke}

Ketidakmandirian adalah kondisi individu yang tidak dapat melakukan aktivitas dalam memenuhi kebutuhan sehari-hari dengan sendirinya akibat masalah yang dialami seperti tubuh menjadi kaku, artikulasi dalam berbicara kurang jelas, dan berjalan tidak sempurna. Perubahan fisik yang dialami mengakibatkan partisipan tidak dapat melakukan aktivitas secara mandiri sehingga tergantung pada orang lain dalam melakukan aktivitas sehari-hari. Hal ini dilihat dari hasil wawancara partisipan:

"Saat pergi ke tempat pengobatan dan memegang saat berjalan di luar rumah karena takut jatuh” (P1, 90-100). 
"Ibu tidak bisa jalan sendiri di luar rumah karena tongkat takut jatuh" (P2, 80-90)

"Mama punya badan kanan kaku, tidak dapat berjalan dengan sendiri dan badan bagian kiri terasa lemas, karena sudah jarang aktivitas." (P3, 110-120)

"Semua aktivitas sehari-hari yang dilakukan, sepenuhnya dibantu oleh anak-anak atau cucu” $(\mathrm{P} 4,110-120)$

Aktivitas sosial yang sebelumnya dilakukan partisipan seperti kegiatan organisasi gereja dan kegiatan-kegiatan di lingkungan tidak lagi dilakukan oleh partisipan disebabkan karena perubahan fisik yang dialami. Berikut ungkapan partisipan:

"Sekarang sudah tidak bisa mengikuti organisasi gereja maupun sosial seperti memandu KKR" (P1, 140-150)

"Semenjak sakit tidak bisa pergi ibadah tidak dapat melakukan aktivitas apapun di luar rumah seperti ibadah pantai" (P2, 130-140)

"Semenjak sakit bapak tidak bisa pergi ke gereja dan tidak bisa lakukan banyak kegiatan diluar rumah bersama teman-teman" (P3, 170180)

"Sejak jatuh sakit tidak bisa mengikuti kegiatan sosial apapun, tidak bisa menjadi pelayan Tuhan di gereja" (P4, 160-170)

\section{Respon Psiko-Sosial dalam Konteks Budaya}

Respon psikososial yang dialami oleh pasien stroke berbentuk marah, kecewa, tidak menerima keadaan, ingin mati, dan senang dengan lingkungannya. Respon tersebut dipengaruhi oleh budaya orang Ambon terkait dengan konsep sehat sakit yaitu penyakit atau masalah yang terjadi dan dialami dipercaya atau diyakini sebagai hukuman yang diberikan Tuhan akibat dosa yang pernah dilakukan. Pemaknaan tersebut merupakan pengalaman serta kebiasaan yang sering ditunjukkan ketika partisipan mengalami masalah (termasuk masalah kesehatan). Respon yang ditunjukkan seperti penolakan terhadap keadaan, sensitif emosional, hilangnya tujuan hidup, pemaknaan terhadap peristiwa sakit dan hubungan sosial. Berikut penjelasan lebih lanjut mengenai kategori ini:

\section{1) Penolakan terhadap Keadaan}

Penolakan terhadap keadaan adalah respon individu yang tidak menerima keadaannya yang sekarang karena perubahan-perubahan yang dialami yaitu perubahan fisik dan psikis. Keadaan tersebut membuat partisipan merasa tidak percaya dengan apa yang terjadi pada dirinya. Sebagaimana ungkapan partisipan:

"Dulu pernah buat kesalahan meninggalakan keluarga sehingga punya pikiran apa ini hukuman yang Tuhan berikan" (P1, 2030)

"Ya, pasti kaget, takut mati ibu mengatakan ya Tuhan bisa sembuh tidak. Saat dengar ibu hanya mengatakan dalam hati ya Tuhan kenapa sampai bisa sakit seperti ini" (P2, 20-30).

"Bapak setelah tahu menderita stroke yang ada di bapak punya pikiran ya Tuhan kenapa sampai bisa sakit seperti ini bisa sembuh tidak. Karena yang bapak tahu penyakit ini susah untuk sembuh. Apakah ini karena dosa atau kesalahan yang telah dilakukan sehingga bisa sakit seperti ini " (P3, 30-40).

"Ya mama juga kaget kenapa sampai bisa sakit seperti ini. Mama juga bertanya-tanya apa yang mama buat sehingga Tuhan berikan penyakit ini" (P4, 50-60).

\section{2) Sensitif secara Emosional}

Sensitif merupakan respon yang dikeluarkan secara spontan dari individu dalam bentuk yang negatif ketika individu tidak dapat mengontrol perasaannya. Respon tersebut dikeluarkan oleh partisipan ketika ada dalam tekanan dari masalah yang partisipan alam. Berikut ungkapan partisipan:

"Sering menangis karena orang lain bisa beraktivitas sedangkan ibu tidak bisa dan mudah tersinggung serta mudah marah" (P1, 20-30, 4050).

"Setelah sakit ini ibu mudah untuk marah, dan cepat lupa" (P2, 50)

"Bapak semenjak sakit ini paling cepat marah, cepat tersinggung apalagi kalau suruh сиси-сиси dan tidak ikut, oh itu bapak sangat marah" (P3, 60-70).

"Mama sekarang mudah marah dan lebih banyak diam" (P4, 70-80).

\section{3) Hilangnya Tujuan Hidup}

Perubahan-perubahan fisik dan psikis yang dialami akibat penyakit stroke membuat partisipan tidak dapat melakukan aktivitas, merasa tidak berguna, dan sudah lelah karena proses penyembuhan yang lama. Hal ini membuat partisipan merasa tidak memiliki tujuan hidup. Berikut ungkapan partisipan:

"Karna dulu bisa melakukan apa saja tetapi setelah sakit tidak bisa melakukan apaapa. Sampai ibu berpikir kenapa tidak mati saja karna mati hari ini dan besok sama saja" (P1, 30-40). 
"Semenjak sakit tidak dapat beraktivitas dan membantu anak-anak terkadang menangis kenapa sampai sakit seperti ini" (P2, 30-40)

"Penyakit ini susah untuk sembuh terkadang punya pikiran ya Tuhan kapan bapak mati karena sudah sangat cape dengan keadaan seperti ini" ( $\mathrm{P} 3,30-40)$.

\section{4) Pemaknaan terhadap Peristiwa Sakit}

Menurut partisipan sakit yang dialami sudah rencana dari Tuhan dan mungkin ada hikmat di balik sakit yang dialami. Berikut ungkapan partisipan:

"Ibu selalu dekat dengan Tuhan karena ibu yakin ada hikmat dari ibu punya penyakit ini" (P1, 300-310).

"Ya apa yang bisa ibu lakukan lagi dengan kondisi seperti ini jadi yang sisi positif dari penyakit yang ibu derita ini ibu merasa lebih bersyukur saja karena ibu yakin ada rencana Tuhan dibalik penyakit ini" (P2, 350-355).

\section{5) Hubungan sosial}

Menurut partisipan hubungannya dengan lingkungan sosial itu baik, tidak ada perubahan dari sebelum sakit hingga saat ini. Partisipan merasa senang karena lingkungan menerima kondisinya yang sekarang. Berikut deskripsi partisipan:

"Ibu selalu mempunyai hubungan baik dengan lingkungan sampai saat ini. Mereka selalu membantu ibu” (P1, 120-130).

"Tetap menjalin hubungan baik, mereka sering datang untuk bercerita dengan ibu. Mereka selalu membuat saya merasa senang" (P2, 110-120).

"Bapak selalu menjalin hubungan baik dengan semua tetangga dari sebelum sakit sampai sekarang jadi tidak ada yang berubah" (P3, 150-160).

"Mama selalu punya hubungan baik dengan semua orang dari sebelum sakit sampai sudah sakit ini mama selalu berbuat baik saja" (P4, 140-150).

\section{Strategi Koping dalam Konteks Budaya}

Strategi koping adalah suatu cara yang dilakukan untuk menguasai, mentoleransi, mengurangi, menangani dampak dari masalah yang dialami oleh partisipan stroke. Strategi koping yang digunakan adalah usaha pengobatan, pengalihan diri, dan dukungan spiritual dan pelarian dari. Masalah yang dialami partisipan diyakini sebagai hukuman dari Tuhan akibat dosa yang dilakukan sehingga mereka percaya masalah yang dialami akan diberikan jalan keluar dengan meminta pengampunan dari Tuhan. Setiap mengalami masalah, solusi yang ditempuh partisipan adalah lebih mendekatkan diri kepada Tuhan. Berikut penjelasan lebih lanjut dari kategori ini:

\section{1) Usaha Pengobatan}

Setelah mengalami stroke partisipan berusaha melakukan berbagai pengobatan seperti terapi dan meminum obat agar mendapatkan perubahan yang lebih baik menuju kesembuhan. Hal ini yang diungkapan partisipan:

"Dari semenjak mengalami stroke ibu mengikuti pengobatan seperti terapi dan pergi ke RS untuk chek up" (P1, 200-210).

"Ibu hanya mengikuti terapi medis tidak ada terapi tradisional yang ibu lakukan" (P2, 210-220).

"Semenjak sakit bapak mengikuti pengobatan medis yaitu terapi dan meminum obat-obatan"'(P3, 240-250).

"Sekarang ini mama tetap menjalani pengobatan seperti meminum obat walaupun tidak ada perkembangan. mama hanya berdoa untuk Tuhan minta kesembuhan dan mam yakin Tuhan punya kuasa atas segala yang terjadi untuk mama” (P4, 230-240).

\section{2) Pengalihan Diri}

Masalah yang dihadapi individu mengakibatkan tekanan psikologi sehingga individu perlu mempunyai cara untuk meminimalkan tekanan yang dirasakan. Hal ini dirasakan oleh partisipan sehingga strategi yang digunakan adalah pengalihan diri seperti menonton TV dan bercerita dengan orang-orang sekitar. Sebagaimana diungkapkan partisipan:

"Ibu selalu berdoa dan mengkhayal bisa seperti yang dulu dan hal-hal yang indah yang dilakukan sebelum sakit”(P1, 270-280).

"Biasanya tetangga-tetangga datang duduk bercerita dengan ibu dan nonton TV, dengan begitu ibu tidak terlalu pikiran karena ibu menyibukan diri dengan hal-hal seperti itu' (P2, 300)

"Bapak kumpul dengan teman-teman untuk bercanda dengan begitu bapak dapat melupakan masalah ini." (P3, 220-230)

"Mama berdoa minta dari Tuhan berikan kekuatan, pikiran-pikiran positif, duduk nonton $T V^{\prime \prime}(\mathrm{P} 4,310)$.

\section{3) Dukungan Spiritual}

Selain strategi yang digunakan seperti usaha pengobatan dan pengalihan diri. Partisipan juga memilih dukungan spritual sebagai salah 
satu cara untuk mengatasi tekanan akibat masalah yang dihadapinya. Berikut ungkapan partisipan:

"Ibu selalu berdoa dan beribadah kepada Tuhan karena ibu yakin Tuhan pasti memberikan kesembuhan" (P1, 180-190).

"Ibu lebih bersyukur saja karena ibu yakin ada rencana Tuhan, ibu sekarang lebih dekat dan bersyukur kepada Tuhan karna ibu yakin Tuhan dapat memberikan kesembuhan" (P2, 340-350).

"Bapak lebih banyak sabar saja dan berdoa" (P3, 330-335)

"Mama selalu berdoa dan beribadah pada semua masalah yang mama hadapi dan menaruh banyak pengharapan buat Tuhan Yesus" (P4, 310-320)

\section{4) Dukungan sosial}

Strategi koping juga diberikan lingkungan berupa dukungan sosial bagi partisipan. Dukungan sangat penting bagi partisipan yang mengalami stroke baik dukungan dari keluarga maupun lingkungan karena dengan adanya dukungan partisipan dapat bersemangat menjalani kehidupannya, menerima keadaannya dan dapat mengatasi tekanan yang dialami. Berikut ungkapan partisipan :

"Selama ibu sakit tanggapan lingkungan terhadap ibu selalu baik, memberikan dukungan dan membantu ibu saat ibu meminta tolong. ibu rasa senang karena mereka peduli dan memberikan dukungan kepada ibu"(P1, 130140).

"Keluarga selalu memberikan dukungan terhadap ibu dari sebelum sakit sampai saat ini. Ibu merasa senang karena keluarga peduli terhadap ibu” (P1, 250-270).

"Tetap menjalin hubungan baik. Mereka sering datang untuk bercerita dengan ibu. Mereka selalu membuat ibu merasa senang "(P2, 110-120).

"Iya selalu anak-anak berikan dukungan untuk ibu. ibu sangat rasa senang karena ada yang peduli, ada yang memperhatikan, mencari tempat pengobatan jadi sangat bersyukur mempunyai kelaurga yang saling megasihi" (P2, 270-280).

"Keluarga selalu berikan dukungan buat mama dari sebelum sakit sampai sekarang. mama merasa senang, anak-anak selalu berikan dukungan par mama" (P4, 280-300).

\section{PEMBAHASAN}

Perubahan fisik akibat stroke yang dialami partisipan mengakibatkan yang bersangkutan tidak dapat melakukan aktivitas secara mandiri atau memerlukan bantuan orang lain. Situasi ini menimbulkan perasaan ketergantungan dalam melakukan aktivitas sehari-hari. Perubahan tubuh berupa alat gerak akibat stroke mengakibatkan aktivitas sehari-hari dilakukan dengan bantuan orang lain (Herawati, 2014). Hasil penelitian Mertha dan Laksmi juga mengatakan bahwa pasien stroke cenderung mengalami ketergantungan pada orang lain karena kekuatan otot yang lemah dan kurang dilatih (Mertha \& Laksmi, 2013). Rayanti dkk, (2015) pun melaporkan bahwa akibat stroke, penderita mengalami keterbatasan fisik sehingga membatasi aktifitas sehari-harinya.

Perubahan fisik yang dialami seseorang dapat menimbulkan respon psikisosial yang merupakan respon terhadap suatu perubahan dalam kehidupan yang bersifat psikologis dan sosial. Respon yang ditunjukkan oleh seseorang dapat berupa respon yang maladaptif dan adaptif. Respon maladaptif adalah respon negatif yang dikeluarkan seseorang terhadap suatu masalah, sedangkan respon adaptif adalah respon positif dikeluarkan seseorang terhadap suatu masalah (Reynald, 2016). Partisipan berespon pada keduanya baik maladaptif maupun adaptif. Bentuk respon maladaptif dari partisipan adalah sensitif emosional, menolak keadaan dan hilang tujuan hidup. Sensitif emosional yang dikeluarkan partisipan adalah mudah marah, sedih, dan kecewa. Bentuk penolakan terhadap keadaan diungkapkan partisipan bahwa ia tidak percaya dengan penyakit yang dialami dan bertanya kepada Tuhan alasan ia bisa mendapat penyakit seperti ini, apakah ini akibat dosa yang dilakukannya? Selain itu bentuk kehilangan tujuan hidup yang diungkapkan partisipan adalah ia merasa lelah dengan keadaan yang sekarang dan memiliki pikiran untuk mati. Hal ini sejalan dengan penelitian Kartini, dkk yang mengemukakan bahwa responden dari pasien stroke mengalami perubahan konsep diri negatif yang lebih besar dibanding konsep diri positif (Kartini, dkk., 2013). Selain itu penelitian ini juga sejalan dengan Sawab, dkk yang menyatakan bahwa klien paska stroke merasakan kehilangan kemampuan fungsional karena penyakit yang mengubah citra tubuhnya sehingga membuat klien memiliki harapan yang negatif (Sawab, dkk., 2015). Bentuk respon yang adaptif dari partisipan berupa pemaknaan sakit dan hubungan sosial. Pemaknaan sakit oleh partisipan adalah sebagai rencana atau kehendak Tuhan. Penelitian ini selaras dengan hasil penelitian Maria bahwa penyakit diyakini sebagai "penggugur dosa" yang berarti jalan untuk mendekatkan diri kepada Tuhan sumber kekuatan 
(Turnip, dkk., 2013). Respon sosial yang diungkapkan partisipan adalah bahwa hubungan partisipan dengan lingkungan baik dan tidak ada perubahan sebelum sakit hingga sakit. Partisipan senang dengan lingkungannya walaupun partisipan tidak dapat mengikuti kegiatan sosial seperti dulu namun lingkungan tetap menerima kondisi partisipan. Individu merasa senang bila mendapat dukungan dari keluarga dan lingkungan. Rayanti, dkk., (2018) mengatakan adanya korelasi (r: 0,730) antara dukungan keluarga dan activity of daily living (ADL), sehingga semakin tinggi dukungan keluarga maka semakin terpenuhi kebutuhan ADL pada penderita paska stroke. Dukungan keluarga membuat individu merasa kuat untuk menghadapi penyakit yang dialami (Herawati, 2014).

Respon psikososial maladaptif dan adaptif merupakan respon yang sering ditunjukkan dan sudah menjadi kebiasaan ketika partisipan mengalami masalah, sehingga membutuhkan strategi koping untuk mengatasinya. Strategi koping didefinisikan sebagai upaya langsung untuk mengatasi tekanan akibat masalah yang dialami (Fauziannisa \& Tairas, 2013). Strategi koping digunakan secara berbeda dari individu yang satu dengan individu lainnya dan dari satu peristiwa dengan peristiwa lainnya. Umumnya setiap individu menggunakan strategi koping yang sudah pernah digunakan sebelumnya dan berhasil. Bila strategi koping tersebut tidak berhasil pada situasi tertentu, maka strategi lain dapat dipertimbangkan (Suyanta \& Ekowarni, 2012). Berdasarkan hasil penelitian, partisipan memiliki dua strategi koping yang digunakan sebagai cara dalam mengatasi masalah yang dialami. Strategi yang digunakan partisipan adalah emotional focus coping dan problem focus coping. Problem focused coping ialah koping yang berfokus pada masalah, sedangkan emotion focused coping ialah bentuk koping yang mengatur respon emosional terhadap situasi yang menekan (Lusiani \& Budiman, 2016). Emotional focus coping yang digunakan partisipan dalam penelitian ini adalah pengalihan diri yang merupakan cara untuk melupakan sejenak masalah yang sedang dialami agar mengurangi tekanan yang dirasakan yaitu dengan duduk bercerita, bercanda bersama tetangga dan teman, memikirkan hal-hal yang positif dan mengkhayal hal-hal yang indah. Hal ini sejalan dengan penelitian Lusiani yang menyatakan bahwa usaha untuk mengatasi situasi menekan dengan lari dari situasi tersebut atau menghindarinya seperti reaksi berkhayal dan usaha menghindarkan atau melarikan diri dari masalah yang dihadapi
(Lusiani \& Budiman, 2016). Strategi emosional yang digunakan individu adalah dengan berpikir positif dan optimis dalam menghadapi masalah (Prawesti, 2013).

Selain strategi emosional yang digunakan, terdapat strategi koping lain, yaitu yang berfokus pada masalah. Problem focus coping yang digunakan partisipan adalah usaha pengobatan, dukungan spiritual dan dukungan sosial. Usaha pengobatan yang dilakukan partisipan adalah pengobatan secara medis yaitu dengan terapi dan minum obat. Partisipan juga mengungkapkan bahwa selama sakit tidak pernah melakukan pengobatan tradisional. Dukungan spiritual yang digunakan partisipan untuk mengatasi masalah adalah beribadah dan berdoa kepada Tuhan, partisipan juga mengatakan bahwa yakin dan percaya akan diberikan kesembuhan oleh Tuhan. Purnomo (2014) dalam hasil penelitiannya juga menjelaskan hal yang sama bahwa pasien stroke cenderung tidak menyalahkan diri sendiri dan Tuhan dengan keadaan yang dialaminya. Namun, mereka akan cenderung lebih mencari hikmah dari setiap kejadian dalam hidupnya dan dapat lebih mendekatkan diri pada Tuhan Yang Maha Esa. Menurut Herawati (2014) dalam penelitiannya pengalaman individu dalam menghadapi perubahan citra tubuh adalah dengan usaha mencari bantuan untuk kesembuhan, baik itu berupa herbal alternatif ataupun medis dan mencari dukungan spiritual. Hasil penelitian yang dilakukan Mardiana, dkk., (2013) juga mengungkapkan bahwa strategi koping pada penderita kanker servik untuk mengatasai masalah yang dihadapi adalah dengan terus mencari tahu informasi dan pengobatan untuk dapat mengurangi nyeri. Selain itu staregi koping juga datang dari lingkungan berupa dukungan dari keluarga dan lingkungan bagi partisipan seperti membantu, peduli dan memberikan dukungan kepada partisipan. Hal ini yang membuat partisipan menjadi semangat dan merasa senang dalam menjalani kehidupannya yang sekarang. Penjelasan tersebut sejalan dengan penelitian Karunia (2016) yang mengatakan bahwa responden yang mendapat dukungan baik dari keluarga membuat mereka bersemangat untuk melakukan rehabilitasi. Hasil penelitian Hasan \& Rufaidah (2013), juga mengungkapkan bahwa penderita stroke mendapat dukungan berupa informasi dan perhatian dari lingkungan melalui interaksi.

Berdasarkan teori yang dikemukakan oleh Lazarus dan Folkman dalam penelitian Maryam (2017) mengemukakan bahwa strategi koping sering dipengaruhi oleh latar belakang budaya 
dan pengalaman dalam menghadapi masalah. Respon dan strategi koping yang digunakan partisipan dipengaruhi oleh pengalaman masa lalu dan kebiasaan partisipan. Budaya yang diyakini partisipan adalah penyakit atau masalah yang dialami merupakan hukuman dari Tuhan akibat dosa atau kesalahan yang dilakukan sehingga cara mereka untuk mengatasi masalah adalah meminta pengampunan dan meyakini bahwa pasti ada jalan keluar atau kesembuhan dari Tuhan. Budaya Ambon dikenal dengan sebutan "Dosa Leluhur" yang artinya perbuatan yang melanggar aturan atau kesalahan yang dilakukan oleh seseorang kepada "Upu Lanite" atau Tuhan sehingga mendapat hukuman berupa kegagalan, penyakit, dan kematian. Pada seseorang yang mengalami masalah akibat "Dosa Leluhur" cara untuk mengatasi masalah tersebut adalah memanjatkan doa pengampunan atau doa pelepasan. Selain itu dalam budaya Ambon, masyarakat mengenal sebutan "Kaul" sebagai salah satu sanksi atas pelanggaran yang dilakukan artinya bahwa ketika seseorang mengucapkan janji dan tidak menepatinya maka akan mengalami masalah seperti sakit sampai mati. Seseorang yang sakit akibat "Kaul" cara mengatasinya yaitu dengan berdoa dan

\section{DAFTAR PUSTAKA}

Amalia, S. (2010). Hubungan Sanitasi Lingkungan dan Faktor Budaya dengan Kejadian Diare pada Anak Balita di Desa Toriyo Kecamatan Bendosari Kabupaten Sukoharjo. Jurnal Unimus.

Badan Penelitian dan Pengembangan Kesehatan. (2014). Pokok-Pokok Hasil Riskesdas Indonesia 2013. Jakarta: Lembaga Penerbit Balitbangkes.

Fauziannisa, M. \& Tairas, M. M. W. (2013). Hubungan antara Strategi Coping dengan Self-efficacy pada Penyalahguna Narkoba pada Masa Pemulihan. Jurnal Psikologi Kepribadian Dan Sosial, 2(3), 136-140.

Fahrudin, A. \& Wahyuni, D. (2004). Modul Diklat Pekerjaan Sosial Medis. Balai Besar Pendidikan Dan Kesejahteraan Sosial.

Ghani, L., Mihardja, L. K., \& Delima, D. (2016). Faktor Risiko Dominan Penderita Stroke di Indonesia. Buletin Penelitian Kesehatan, 44(1), 49-58. https://doi.org/10.22435/bpk.v44i1.4949.4 9-58

Gorman, Linda M. \& Sultan, Donna F. (2008). Psychosocial nursing For General Patient Care (3rd ed.). America: F A Davis memenuhi janji atau kaul-nya. Pemahaman ini didukung oleh hasil penelitian Frans yang mengatakan bahwa masyarakat Ambon percaya adanya suatu kekuatan yang bersifat sakral, mereka percaya bahwa kenyamanan, keadilan dan kesejatraan bersumber dari kekuatan "Upu Lanite" yang merupakan sebutan mereka kepada Tuhan yang menciptakan langit dan bumi dan juga sebagai "Leluhur atau tete/nenek moyang". Pengakuan ini menjelaskan bahwa segala sesuatu yang terjadi pada mereka diberikan oleh Tuhan. Penghayatan dan pengakuan terhadap "Upu Lanite" dapat menolong mereka memahami hubungannya dengan leluhur, masa lampau, sekaligus menolong mereka menghadapi krisis atau masalah yang dihadapi (Thomas, 2015).

\section{SIMPULAN}

Perubahan fisik yang dialami partisipan akibat stroke menimbulkan respon psikososial berupa maladaptif dan adaptif. Adapun strategi koping yang digunakan untuk mengatasi masalah adalah dengan emotional coping dan problem focus coping yang dipengaruhi oleh budaya Ambon.

\section{Company.}

Hartanti. (2012). Peran Sense of Humor dan Dukungan Sosial pada Tingkat Depresi Penderita Depresi Pasca Stroke. Jurnal Anima, 17(2), 107-119.

Hasan, N., \& Rufaidah, E. R. (2013). Hubungan antara Dukungan Sosial dengan strategi Koping pada Penderita Stroke RSUD Dr . Moewardi Surakarta. Talenta Psikologi, 2(1), 41-63.

Hastuti, I. D., Setiawan, R. dan Fikri, J. (2014). Hubungan Dukungan Sosial dengan Kualitas Hidup pada Penderita Tuberkulosis Paru di Balai Kesehatan Kerja Masyarakat Propvinsi Jawa Barat Tahun. Bhakti Kencana Medika, 4(1), 1-74

Herawati, N. (2014). Studi Fenomenologi Pengalaman Perubahan Citra Tubuh pada Klien Kelemahan Pasca Stroke di RS DR M Djamil Kota Padang. Jurnal Keperawatan Jiwa, 2(1), 31-40.

Kartini, Murtiani, dan Iilyas, M. (2013). Hubungan Dukungan Keluarga dengan Perubahan Konsep Diri pada Pasien Pasca Stroke di Poliklinik Saraf Rumah Sakit Khusus Daerah Provinsi Sulawesi Selatan. 
Jurnal Ilmiah Kesehatan, 3(1), 107-113.

Karunia, E. (2016). Hubungan Antara Dukungan Keluarga dengan Kemandirian Activity Of Daily Living Pasca Stroke. Jurnal Berkala Epidemiologi, 4(2), 213-224. https://doi.org/10.20473/jbe.v4i2.2016.213

Lusiani, I., \& Budiman, A. (2016). Hubungan Dukungan Sosial dengan Coping Strategy pada Penderita Stroke di Rumah Sakit Al Islam Bandung. Prosiding Psikologi, 2(2), 613-618.

Mardiana, D., Ma'rifah, A. R., \& Rahmawati, A. N. (2013). Hubungan Mekanisme Koping dengan Kualitas Hidup Penderita Kanker Servik di RSUD Prof. dr. Margono Soekarjo Purwokerto. Jurnal Keperawatan Maternitas, 1(1), 9-20.

Maryam, S. (2017). Strategi Coping: Teori dan Sumber Dayanya. Jurnal Konseling Andi Matappa, 1(2), 101-107.

Maulanadari, N. (2010). Strategi Koping Menghadapi Stres Pada Penderita Kanker Paru. [Skripsi]. Surakarta: Fakultas Psikologi Universitas Muhammadiyah Surakarta.

Mertha, I., \& Laksmi, A. (2013). Pengaruh Terapi Latihan Terhadap Kemandirian Melakukan Aktivitas Kehidupan Seharihari Pasien Stroke Iskemik. Jurnal Skala Husada, 10(1), 60-64.

Prawesti, D. (2013). Strategi Koping Internal Keluarga Pasien Stroke Menurut Teori Pearlin Dan Schooler. Jurnal STIKES, 6(2), 1-13.

Purnomo, N. A. S. (2014). Resiliensi pada Pasien Stroke Ringan Ditinjau dari Jenis Kelamin. Jurnal Ilmiah Psikologi Terapan, 2(2), 241-262. https://doi.org/10.1192/bjp.205.1.76a

Rayanti, R. E., Putra, K.P., Nenobanu, M. E. (2018). Dukungan Anggota Keluarga dan Activity of Daily Living (ADL) pada Penderita Post Stroke di Klinik Utama Graha Medika Salatiga. Indonesian Journal On Medical Science, 5(1). 48-53.

Rayanti, R. E. Karwur, F. F. Karwur, D.J. (2015). The Daily Life of Post Stroke Patients in
Tomohon City, North Celebes, Indonesia. Silliman Journal, 56(1). 121-142.

Reynald, D.I. (2016). Dampak Psikososial pada Individu yang Mengalami Pelecehan Seksual di Masa Kanak-kanak. Psikoborneo, 4(2), 312-320

Sawab, Moch. Bahrudin, Novy, H. C. D. (2015). Pengalaman Keputusasaan Stroke Survivor di Kota Semarang. Jurnal Ners, 10(1), 125-132.

Safaria, T. \& Nofrans E. S. (2012). Manajemen Emosi. Jakarta: Bumi Aksara.

Suantika, I. W. (2007). Memediasi Nilai-Nilai Luhur Budaya Maluku Masa Lampau. Kapata Arkeologi, 2(3), 1-20.

Sugiyono. (2009). Metode Penelitian Kuantitatif dan Kualitatif. Bandung: Alfabeta.

Suyanta, \& Ekowarni, E. (2012). Pengalaman Emosi dan Mekanisme Koping Lansia yang Mengalami Penyakit Kronis. Jurnal Psikologi, 39(2), 208-221.

Taluta. (2014). Hubungan Tingkat Kecemasan dengan Mekanisme Koping pada Penderita Diabetes Melitus Tipe II di Poliklinik Penyakit dalam Rumah Sakit Umum Daerah Tobelo Kabupaten Halmahera Utara. Jurnal Keperawatan, 1(1), 1-9.

Thomas, F. (2015). Pendidikan Nilai dalam Tradisi Pela (Kajian Etnografis Masyarakat Ambon ). Jurnal Pendidikan Humaniora, 3(2), 122-133.

Turnip, M., Keliat, B. A., Susanti, Y., \& Putri, E. (2013). Fenomena Konflik, Ansietas, dan Depresi pada Klien Kanker Setelah Didiagnosa Satu Tahun dan Mendapat Terapi Di Rumah Sakit Umum. Jurnal Ners, 10(2), 242-249.

Yuanita S, Ratna., Sutriningsih, Ani, Catur A W.R. (2015). Mekanisme Koping Keluarga Menurunkan Tingkat Kecemasan Kecemasan Keluarga Pasien Stroke. Jurnal Care, 3(2), 18-25.

Yastroki. (2012). Tahapan Terapi Stroke Akut. http://www.yastroki.or.id/read.php?id=14, online accessed on 12 Oktober 2017. 